Vol. 12(7), pp. 387-893, 10 April, 2017

DOI: 10.5897/ERR2017.3144

Article Number. FC 4A76663536

ISSN 1990-3839

Copyright $\odot 2017$

Educational Research and Reviews

Author(s) retain the copyright of this artic le

http:// www.academic joumals.org/ERR

\title{
Analysis of computer self-efficacy of Turkish undergraduate students in the sport management departments
}

\author{
Dilşad Çoknaz ${ }^{1 *}$ and Işıl Aktağ ${ }^{2}$ \\ ${ }^{1}$ Sport Management Department, Dilşad Çoknaz, Abant İzzet Baysal University, Bolu, Turkey. \\ ${ }^{2}$ Physical Education Teaching Department, Işıl Aktağ, Abant İzzet Baysal University, Bolu, Turkey.
}

Accepted 12 January, 2017; Accepted 13 March, 2017

\begin{abstract}
In this study computer self-efficacy of Turkish undergraduate sport management students was investigated. There were a total of 295 sport management students from three universities. Data were collected by survey which was developed by Compeau and Higgins, 1995, translated to Turkish and adapted for students by Aktag, 2013. The results showed that there was a significant positive correlation among students' computer self-efficacy, performance outcome, personal outcome, affective outcome and a significant negative correlation between computer self-efficacy and anxiety level. Although there is no difference between males and females in terms of computer self-efficacy in the study, the high level of anxiety of female students indicates that they should be supported in technology. Students who are taking computer course received the highest computer self-efficacy than others who were not.
\end{abstract}

Key words: Computer self-efficacy, anxiety, sport management students, gender.

\section{INTRODUCTION}

The incorporation of technology into the teaching and learning has become an important piece in every part of higher education (Saleh, 2008). Students' acquisition of a high level of technological skills and ability is considered a basic part of the $21^{\text {st }}$ century curriculum, equivalent to importance of reading and writing (UNESCO, 2000 as cited in Giles and Kent, 2016). Computer and technology education has become a necessary part in educational institutions' curriculum (Hsu and Huang, 2006). Turkish Council of Higher Education (TCHE) recommends universities to offer computer courses to help students become more proficient in fundamental computer skills and have knowledge about basic concepts of technology. Commission on Sport Management Accreditation (COSMA) indicated that sport management programs need to include technology and computer courses in their programs (COSMA, 2016).

According to COSMA (2016), students from sport management departments may have technological advancements such as web streaming, instant replay for

\footnotetext{
*Corresponding author. E-mail: coknaz_d @ibu.edu.tr.
} 
officials, injury rehabilitation and social media in addition to use of technology in the classroom to strengthen and stimulate learning. The use of technology in the form of various computer programs is prevalent within many of these operating areas inside sport organizations (Diacin and Van Sickle, 2014).

There is a growing need for technology in the undergraduate sport management curriculum (Hjerpe, 2009). Advancements in technology help to "globalization of sport" and hence the sport management classroom must exhibit that to properly train students for entry into this business (Masteralexis et al., 2012 as cited in Hardin and Pate, 2015). Although a computer course is an effective factor in learning how to use a computer, it does not guarantee that the student will be able to use a computer in every stage of daily life (OECD, 2004 as cited in Tezci, 2011).

For a variety of reasons, there are university students who do not have fully integrated computers in their professions or daily life. Self-efficacy might be one of the reasons that influence individuals' computer usage.

Self-efficacy beliefs have been associated with the studies of Albert Bandura (1997) who defined selfefficacy as "beliefs in one's capabilities to organize and execute the courses of action required to produce given attainments". An individual's high level self-efficacy might lead to the accomplishing tasks that exceed his or her capabilities, while low self-efficacy might result in the underestimation of one's abilities, thus, leading to under achievement (Bandura, 1982).

Computer self-efficacy (CSE) is based on the belief in one's ability to use advanced computer skills (Compeau and Higgins, 1995). If individuals have high self-efficacy, they tend to see themselves as adequate in using computers. On the contrary, individuals who have low self-efficacy become more disappointed and distressed working with computers and hold back themselves to use computers when they face an obstacle (Karsten and Roth, 1998).

Compeau et al. (1999) developed a model related with CSE. According to this model there is a connection between cognitive factors (self-efficacy, performance and personal related outcome expectations), affective factors (affect and anxiety) and computer usage. Self-efficacy exhibits an individual's beliefs in his/her ability to engage in specific and complicated actions to use computer technology and high self-efficacy brings some expectations as an outcome. Performance related expectations such as rise in job or school performance and, personal expectations such as raises, promotions or praises. Effect and anxiety are the emotional responses of individuals for using computers. While effect characterized as positive feelings such as, enjoyment in using computer, anxiety represents negative feelings such as fear or apprehension when using computers.

According to Hsu and Huang (2006), computer use was the most critical element altering CSE, and in order to enhance students' CSE, educators should consider increasing students' computer use. In past research, CSE has been connected as a crucial factor for computerrelated ability and computer practice (Hasan, 2003). Computer experience is integrated in the amount of time an individual has spent working with computers and the different applications they have learned to use. More years of experience and more frequent computer use should give more opportunities to gather CSE information (Karsten and Schmidt, 2008). As individuals gain more experience with computers, their CSE level increases, too (Saleh, 2008; Papastergiou, 2010). In this study, students were asked if they took computer course or not and frequency of computer usage.

Computer anxiety is another reason why individuals use computers ineffectively. The more experience an individual has with computers, the lower the level of anxiety (Compeau et al., 1999; Şimşek, 2011; Korabili et al., 2010).

Gender is another factor that influences the CSE and frequency of computer usage. This issue has been investigated in many studies. Some researchers demonstrated males have more positive attitudes toward computers when compared to females (İşman and Çelikli, 2009; Cassidy and Eachus, 2002) while others reported no difference between males and females (Ünlü and Süel, 2014).

Computer courses serve as a way of ensuring that students work with computers. The relationship of this experience with CSE becomes an important part of practice. Pointed out by Compeau and Higgins (1999) as cited in Stephens (2006) that in educational environments, one of the main advantages of computer self-efficacy is that it can be used to evaluate individuals' access to and the effectiveness of computer education. According to Cassidy and Eachus (2002) in order to employ and effectively exploit computer technology, educators need to address, as a key issue, computer user self-efficacy beliefs in learners. On the basis of all those information, this current study was focused on evaluation of computer self-efficacy in sport management student.

\section{METHODOLOGY}

\section{Purpose of the study}

Using technology in their profession is an important part of being an innovative sport manager. That is why in order to use technology effectively, in this regard; using computers in their daily and professional life, individuals in sport management area must have high computer self-efficacy. For this reason, performance in computer courses needs to be evaluated. Therefore the purpose of this study is to determine the computer self-efficacy, performance outcome, personal outcome, affective outcome and anxiety level of students from sport management departments. And also, to determine the influence of gender, whether they take computer course, if they do the grades obtained from the course, and how often the computer is used on computer self-efficacy.

Hypothesis of this study were as follows: 
1. There is a positive relationship between computer self-efficacy, performance outcome, personal outcome and affective outcome.

2 . There is a negative relationship between computer self-efficacy, personal outcome, performance outcome, affective outcome and anxiety.

3. There is a difference in computer self-efficacy, personal outcome, performance outcome, affective outcome and anxiety level of students according to gender.

4. There is a difference in computer self-efficacy, personal outcome, performance outcome, affective outcome and anxiety level of students whether they took computer course before, taking the course now or have not taken the course yet.

5 . There is a difference in computer self-efficacy level of students according to grades they received from computer course.

\section{Participants}

The subjects of this study were undergraduate students in Sport Management Departments from three universities: Abant Izzet Baysal University (AIBU), Celal Bayar University (CBU) and Sakarya University (SAU). There were 96 female and 199 male with a total of 295 undergraduate students in this study. Participation was voluntary.

\section{Data collection instrument}

In this research, originally developed by Compeau and Higgins (1995) adapted for students and translated to Turkish by Aktag (2013) Computer Self-Efficacy Scale (CSES) was used. Validity and reliability of this scale was conducted by Işıl Aktag in 2013. As a result of factor analysis CSES consists of 5 factors and 28 items. For reliability of the data, the Cronbach alpha was found as 0.88 for the whole scale Aktag (2013). In current study, Cronbach alpha coefficient was determined as .88 for whole scale too.

Even though this scale is called computer self-efficacy scale, it contains 6 parts:

1: The computer self-efficacy (CSE) was measured by 10 items. Participants were asked to indicate their ability to perform a task on computer on a 10 point scale.

2 and 3: Personal outcome (PO) and the performance outcome (PFO) were measured by 9 items in 5 point scale.

4: The affective outcome (AFO) was measured by 5 items with a 5 point scale.

5: The anxiety (A) was measured by 4 items.

6: Computer usage was measured by asking frequency of computer usage at their daily life.

\section{Data collection procedure}

For the data collection AIBU, CBU, and SAU sport management departments were selected because computer course was mandatory. CSES was given to all students in those universities during 2014 and 2015 spring semester. After examining the results of the CSES completed by the students, the scale which was filled incorrectly were eliminated and finally 295 forms were evaluated in the study.

\section{Data analysis}

The data was analysed by using descriptive statistics and independent samples t-test, one-way ANOVA and Pearson correlation coefficient statistical techniques. In order to view the assumption of the data's normality, Kolmogorow-Smirnov normality test was performed. As a result of this analysis it can be stated that the data is distributed normally. The statistical significance level was determined as 0.05 .

\section{FINDINGS}

Research findings related to the computer self-efficacy, anxiety, performance, personal and affective outcomes of the students are shown in Table 1. In the table, the arithmetic mean of participants' CSE, PFO, AFO, PO and A calculations are tabulated with their standard deviations. When Table 2 is explored, a significant positive correlation among the participants' computer self-efficacy and the performance outcome $(r=0.39$, $p=0.000<0.01)$ can be seen. The rest are given respectively as the computer self-efficacy and the affective outcome $(r=0.30, p=0.000<0.01)$, the computer self-efficacy and the personal outcome $(r=0.27$, $p=0.000<0.01)$, the affective outcome and the performance outcome $(r=0.42, p=0.000<0.01)$ and the personal outcome and the performance outcome $(r=0.45$, $p=0.000<0.01)$. However, a negative correlation among participants' anxiety and the computer self-efficacy ( $r=-$ $0.26, p=0.000<0.01$ ) and the affective outcome and the computer self-efficacy $(r=-0.28, \quad p=0.000<0.01)$ were found. According to Table 2, it can be said that as CSE increases, PFO, AO and PO increase as well. On the other hand as $\mathrm{A}$ increases, CSE and AO scores decrease significantly.

Table 3 presents a comparison of the students' computer self-efficacy, the anxiety, the performance, the affective and the personal outcomes according to gender. It is found except anxiety there was no significant difference between male and female students' in their computer self-efficacy, performance, affective and personal outcomes. The only difference between male and female students is found in anxiety scores. Female students' anxiety mean is 8.23 while it was 7.17 for male students' ( $\mathrm{t}(295)=2.45, \mathrm{p}=0.015<0.05)$.

When Table 4 is analyzed, significant differences were found in the computer self-efficacy, the anxiety, the performance and the affective outcomes, of students whether they took computer course, taking it currently or did not take it yet. For CSE, PFO and AO, students who are taking computer course currently had the highest scores among others, respectively $\bar{X}=77.12, \bar{X}=15.25$, and $\bar{X}=20.7$. For $A$, students who are taking computer course currently had the lowest anxiety score among others, $\bar{X}=6.20$.

The findings in Table 5 have revealed the significant differences at students' CSE scores according to the grades from the computer course. In this study grade AA represents the score from computer course is above 90, BA is between $85-89$, BB is $80-84, \mathrm{CB}$ is $75-79, \mathrm{CC}$ is $65-$ 74 , DC is $60-64$ and DD is 55-59. According to the findings, there were significant differences between students who had DD with all other grades except DC. 
Table 1. Mean and S.D. of sport management students' computer self-efficacy, performance outcome, personal outcome, affective outcome and anxiety.

\begin{tabular}{lccc}
\hline Parameter & N & $\bar{X}$ & SD \\
\hline Performance outcome & 295 & 14.94 & 2.86 \\
Affective outcome & 295 & 18.79 & 3.61 \\
Anxiety & 295 & 7.51 & 3.53 \\
Computer self-efficacy & 295 & 71.81 & 19.29 \\
Personal outcome & 295 & 16.08 & 4.71 \\
\hline
\end{tabular}

Table 2. Pearson correlation results of computer self-efficacy, performance outcome, personal outcome, affective outcome and anxiety.

\begin{tabular}{|c|c|c|c|c|c|}
\hline Variable & & Computer self-efficacy & Performance outcome & Affective outcome & Anxiety \\
\hline \multirow{3}{*}{$\begin{array}{l}\text { Performance } \\
\text { Outcome }\end{array}$} & $r$ & $0.394^{*}$ & & & \\
\hline & $\mathrm{p}$ & 0.000 & & & \\
\hline & $\mathrm{N}$ & 295 & & & \\
\hline \multirow{3}{*}{$\begin{array}{l}\text { Affective } \\
\text { Outcome }\end{array}$} & $r$ & $0.302^{*}$ & $0.427^{*}$ & & \\
\hline & $\mathrm{p}$ & 0.000 & 0.000 & & \\
\hline & $\mathrm{N}$ & 295 & 295 & & \\
\hline \multirow{3}{*}{ Anxiety } & $r$ & $-0.269^{*}$ & -0.107 & $-0.280^{*}$ & \\
\hline & $p$ & 0.000 & 0.065 & 0.000 & \\
\hline & $\mathrm{N}$ & 295 & 295 & 295 & \\
\hline \multirow{3}{*}{$\begin{array}{l}\text { Personal } \\
\text { Outcome }\end{array}$} & $r$ & $0.273^{*}$ & $0.455^{*}$ & $0.393^{*}$ & 0.098 \\
\hline & $\mathrm{p}$ & 0.000 & 0.000 & 0.000 & 0.092 \\
\hline & $\mathrm{N}$ & 295 & 295 & 295 & 295 \\
\hline
\end{tabular}

$p<0.01$.

Table 3. $T$ test results of computer self-efficacy, performance outcome, personal outcome, affective outcome and anxiety due to gender.

\begin{tabular}{|c|c|c|c|c|c|c|c|}
\hline Measurements & Gender & $\mathbf{N}$ & $\bar{X}$ & SD & df & $\mathbf{t}$ & $\mathbf{p}$ \\
\hline $\begin{array}{l}\text { Computer } \\
\text { Self-efficacy }\end{array}$ & $\begin{array}{l}\text { Female } \\
\text { Male }\end{array}$ & $\begin{array}{c}96 \\
199\end{array}$ & $\begin{array}{l}73.58 \\
70.96\end{array}$ & $\begin{array}{l}18.14 \\
1981\end{array}$ & 293 & 1.09 & 0.276 \\
\hline $\begin{array}{l}\text { Performance } \\
\text { Outcome }\end{array}$ & $\begin{array}{l}\text { Female } \\
\text { Male }\end{array}$ & $\begin{array}{c}96 \\
199\end{array}$ & $\begin{array}{l}14.83 \\
14.99\end{array}$ & $\begin{array}{l}2.95 \\
2.82\end{array}$ & 293 & -0.454 & 0.650 \\
\hline $\begin{array}{l}\text { Affective } \\
\text { Outcome }\end{array}$ & $\begin{array}{l}\text { Female } \\
\text { Male }\end{array}$ & $\begin{array}{c}96 \\
199\end{array}$ & $\begin{array}{l}18.21 \\
19.07\end{array}$ & $\begin{array}{l}3.95 \\
3.41\end{array}$ & 293 & -1.90 & 0.058 \\
\hline Anxiety & $\begin{array}{l}\text { Female } \\
\text { Male }\end{array}$ & $\begin{array}{c}96 \\
199\end{array}$ & $\begin{array}{l}8.23 \\
7.17\end{array}$ & $\begin{array}{l}3.57 \\
3.47\end{array}$ & 293 & 2.45 & $0.015^{*}$ \\
\hline $\begin{array}{l}\text { Personal } \\
\text { Outcome }\end{array}$ & $\begin{array}{l}\text { Female } \\
\text { Male }\end{array}$ & $\begin{array}{c}96 \\
199 \\
\end{array}$ & $\begin{array}{l}16.04 \\
16.01 \\
\end{array}$ & $\begin{array}{l}4.48 \\
4.83 \\
\end{array}$ & 293 & -0.117 & 0.907 \\
\hline
\end{tabular}

$p<0.05$.

When Table 6 is analyzed, no significant difference was found among students who said they use computers once a week, several times a week and every day. About half of the students use computers every day. This shows us that most students spend a lot of time with computers in their daily life.

\section{DISCUSSION}

In this study, students of the departments of sports 
Table 4. One way ANOVA results of computer self-efficacy, performance outcome, personal outcome, affective outcome and anxiety due to taking computer course.

\begin{tabular}{|c|c|c|c|c|c|c|c|}
\hline Measurements & Course & $\mathbf{N}$ & $\overline{\mathrm{X}}$ & SD & $\mathbf{F}$ & $\mathbf{p}$ & Post Hoc \\
\hline \multirow{3}{*}{$\begin{array}{l}\text { Computer } \\
\text { self-efficacy }\end{array}$} & Yes & 186 & 72.81 & 18.45 & \multirow{3}{*}{4.98} & \multirow{3}{*}{$0.007^{*}$} & Yes-No; no-now \\
\hline & No & 69 & 66.04 & 22.13 & & & \\
\hline & Currently & 40 & 77.12 & 15.59 & & & \\
\hline \multirow{3}{*}{$\begin{array}{l}\text { Performance } \\
\text { outcome }\end{array}$} & Yes & 186 & 15.16 & 2.82 & \multirow{3}{*}{3.43} & \multirow{3}{*}{$0.03^{*}$} & Yes-no \\
\hline & No & 69 & 14.15 & 2.93 & & & \\
\hline & Currently & 40 & 15.25 & 2.72 & & & \\
\hline \multirow{3}{*}{$\begin{array}{l}\text { Affective } \\
\text { outcome }\end{array}$} & Yes & 186 & 18.69 & 3.68 & \multirow{3}{*}{3.85} & \multirow{3}{*}{$0.02^{*}$} & Yes-now; no-now \\
\hline & No & 69 & 18.24 & 3.41 & & & \\
\hline & Currently & 40 & 20.17 & 3.34 & & & \\
\hline \multirow{3}{*}{ Anxiety } & Yes & 186 & 7.53 & 3.72 & \multirow{3}{*}{4.10} & \multirow{3}{*}{$0.01^{*}$} & No-now \\
\hline & No & 69 & 8.21 & 3.23 & & & \\
\hline & Currently & 40 & 6.22 & 2.77 & & & \\
\hline \multirow{3}{*}{$\begin{array}{l}\text { Personal } \\
\text { outcome }\end{array}$} & Yes & 186 & 16.25 & 4.66 & \multirow{3}{*}{0.893} & \multirow{3}{*}{0.410} & \\
\hline & No & 69 & 15.43 & 4.71 & & & \\
\hline & Currently & 40 & 16.45 & 4.93 & & & \\
\hline
\end{tabular}

$p<0.05$.

Table 5. One way ANOVA results of computer self-efficacy due to grades from computer course.

\begin{tabular}{|c|c|c|c|c|c|c|c|}
\hline Measurement & Grades & $\mathbf{N}$ & $\overline{\mathrm{X}}$ & SD & $\mathbf{F}$ & $p$ & Post hoc \\
\hline \multirow{8}{*}{$\begin{array}{l}\text { Computer } \\
\text { self-efficacy }\end{array}$} & AA & 51 & 78.98 & 20.14 & \multirow{8}{*}{5.91} & \multirow{8}{*}{.00} & AA-DD \\
\hline & BA & 20 & 79.60 & 13.75 & & & BA-DD \\
\hline & BB & 36 & 72.83 & 17.92 & & & BB-DD \\
\hline & CB & 24 & 68.54 & 17.03 & & & CB-DD \\
\hline & $\mathrm{CC}$ & 41 & 69.12 & 18.02 & & & CC-DD \\
\hline & DC & 8 & 58.75 & 16.72 & & & \\
\hline & DD & 8 & 45.50 & 11.75 & & & \\
\hline & Total & 188 & 72.10 & 19.22 & & & \\
\hline
\end{tabular}

$p<0.05$.

Table 6. One way ANOVA results of computer self-efficacy due to frequency of computer usage.

\begin{tabular}{llccccc}
\hline Measurement & Computer usage & $\mathbf{N}$ & $\bar{X}$ & SD & F & p \\
\hline \multirow{2}{*}{ Computer } & Once a week & 21 & 68.47 & 19.73 & & \\
Self-efficacy & Several times a week & 117 & 72.23 & 18.43 & 0.345 & 0.709 \\
& Everyday & 157 & 71.94 & 19.93 & & \\
\hline
\end{tabular}

$p<0.05$.

management from three universities were taken as samples. The CSE, anxiety level, performance, affective and personal outcomes investigated in relation to their gender, grade of the computer course and frequency of computer usage.

Pearson correlation coefficient was calculated in order 
to be able to see the relationship of students' CSE, anxiety, performance, personal and affective outcomes. According to the calculations, a low positive correlation among students' CSE, performance outcome, affective outcome and personal outcome scores was found on the other hand it was found a low negative correlation between the anxiety and the CSE and the anxiety and the affective outcome. These results approve the studies of Compeau et al. (1999), the CSE and the outcome expectations are powerful and significant predictor of the affective outcome and the anxiety. Findings of this study are also supported by Şimşek (2011) and Korobili et al. (2010) that the CSE has a negative correlation with the anxiety. Namely as anxiety level decreases so too the level of computer self-efficacy and affective outcome.

The $t$ test results indicated that there was no significant gender related difference in the CSE, the performance outcome, the affective outcome and the personal outcome of the students. The only significant difference between male and female students was found in anxiety scores. Male students had lower anxiety scores $(\bar{X}=7.17)$ than female students $(\bar{X}=8.23)$. Gender differences results were inconsistent. Some of the findings indicated that the male students had higher CSE than the female students. However, much of the literature indicated that there are no differences between genders. Consistently, according to Pamuk and Peker (2009), Teo (2008), Ünlü and Süel (2014) and Zorba (2011) there are no significant differences between males and females in the CSE levels. According to İşman and Çelikli (2009), Şimşek (2011), Papastergiou (2008), and Huffman et al. (2013) on the contrary, male students are more confident as compared to female students in computer usage. Although there was not any significant difference at students' CSE level related to their gender, surprisingly a significant difference was found between the female and male students' anxiety level. Because of their high anxiety level of female students while using computers they could not make any computer related career choices. This might also affect their attitudes towards computer technologies.

Results related to the students' taking computer course and their CSE, the anxiety, the performance, the affective and the personal outcomes showed that the CSE, the performance and the affective outcomes of students who declared they are taking computer course currently had significantly higher than students who declared they have not taken it yet or took it before. Besides, the anxiety scores of students who declared they are taking computer course currently had the lowest among others. In this case, the influence or effectiveness of the computer course for extended period of time needs to be questioned. For students taking computer course may not help them to convince this course is important and worthwhile in their profession and educational life thus accordingly, they have not benefited from this course. Göktaş (2012) found that CSE of students was affected positively after they took computer course. The findings of this study supported this partially. In our case, students who took the computer course had lower anxiety scores than students who had not taken computer course yet. Simultaneously, they have higher CSE scores than the students who have not taken computer course yet. But, the influence of this experience did not last long.

In this study, the students' CSE level was analyzed according to the grades taken from the computer course. It was found that there was a significant difference between DD and the all other grades, except DC. This means that $D D$ is the threshold grade for students to influence their CSE. In terms of students, as long as they do not fail from the course their self-efficacy was not altered. When looked at, the CSE means of the students who took AA from the course was the highest 78.98. Çolak (2013) found a positive correlation between the CSE and the computer grades similar to this work.

The results on the frequency of the computer usage by sport management students show that more than half of the students spend time with computers every day. The CSE of students who said they use computer every day and the ones who use computer several times a week is very close to each other. At this point, we need to questioned students' computer usage. They might use computers communicate with family and friends, gaming or chatting rather than through study related activities. Computer self-efficacy is associate rather to the quality of experience than to the amount of time spending with computers. These results were supported by Özçelik and Kurt (2007). According to the Compeau and Higgins (1995), as the computer usage increases, the computer self-efficacy level is supposed to increase too.

\section{Conclusion}

It is quite important that youngsters who will be professions in the future competencies in using technological tools such as computer in the information age. Because individuals who cannot follow the innovations in technology and cannot use the technology adequately in their professional life will probably be affected negatively. Hence this study focuses on computer self efficacy which is thought to be determinative in the efficient use of computers. Although there is no difference between males and females in terms of computer self-efficacy in the study, the high level of anxiety of female students indicates that they should be encouraged in technology. The difference between DD which is the lowest grade in the search and other grades and if they have computer training or not seems as a factor effecting computer self efficacy. In conclusion it can be said that, educational environment gives opportunities for sport management students to use computers effectively .In this case computer training needs to be supported for sport management students. 


\section{LIMITATIONS AND RECOMMENDATIONS}

This study is related with computer self-efficacy of sport management students. When it was considered the rapid development in Information Technologies (IT), the topic of current study may look like noncurrent. But computer courses are provided for university students as a main course for technology training so to study about computer self-efficacy became a meaningful in the field of sport management in Turkey. Thereby, researchers' first priority was to study in this area but in future studies it is suggested that to focus usage of new technologies in sport management or for sport managers.

\section{CONFLICT OF INTERESTS}

The authors have not declared any conflict of interests.

\section{REFERENCES}

Aktag I (2013). Changes in computer self-efficacy of pre-service teachers in physical education. Int. J. Acad. Res. 5(6):169-177. Doi: 10.7813/2075-4124.2013/5-6/B.27

Bandura A (1997). Self-efficacy: The exercise of control. W.H. Freeman and Company, New York.

Bandura A (1982). Self-efficacy mechanism in human agency. Am. Psychol. 37:122-147.

Cassidy S, Eachus P (2002). Developing the computer user selfefficacy (cuse) scale: investigating the relationship between computer self-efficacy, gender and experience with computers. Educ. Computing Res. 26(2):133-153.

Çolak S (2013).The relationship among computer self-efficacy scores, demographic characteristics, and grades in computer courses of students at the school of physical education and sports. Educ. Res. Rev. 8(8):374-377. Doi:10.5897/ERR2013.1428.

Compeau DR, Higgins CA (1995). Application of social cognitive theory to training for computer skills. MIS Q. 118-143.

Compeau DR, Higgins CA, Huff S (1999). Social cognitive theory to training and individual reactions to computing technology: A longitudinal study. MIS Q. 23(2):145-158.

COSMA (2016). Accreditation principles manual and guidelines for selfstudy preparation N, http://www.cosmaweb.org/accreditationmanuals.html,

Diacin MJ, VanSickle JL (2014). Computer Program Usage in Sport Organizations and Computer Competencies Desired by Sport Organization Personnel at University of Indianapolis. Int. J. Appl. Sports Sci. 26(2):124-137.

Giles RM, Kent AM (2016). An investigation of preservice teachers' selfefficacy for teaching with technology. Asian Educ. Stud. 1(1):32-40. doi:10.20849/aes.v1il.19.

Göktaş Z (2012). The attitudes of physical education and sport students towards information and communication technologies. Tech Trends, 56 (2):22-30.

Hardin R, Pate RJ (2015). Emerging Technology in Sport Management Education: Guest Editors' Introduction. Sport Manage. Educa. J. 9:77-78. doi.org/10.1123/SMEJ.2015-0029

Hasan B (2003). The influence of specific computer experiences on computer self-efficacy beliefs. Computers in Human Behavior 19:443450.

Hjerpe K (2009). The absence of technology in undergraduate sport management curriculum and its relationship to intercollegiate and professional. Unpublished $\mathrm{PhD}$. Dissertation, Robert Morris University, School of Education and Social Sciences, USA.
Hsu Wen-Kai K, Huang Show-Hui S (2006). Determinants of computer self-efficacy-an examination of learning motivations and learning environments. J. Educ. Comput. Res. 35(3):245-265.

Huffman AH, Whetten J, Huffman WH (2013). Using technology in higher education: The influence of gender roles on technology selfefficacy. Computers in Human Behavior.29:1779-1786.

İşman A, Çelikli GE (2009). How does student ability and self-efficacy affect the usage of computer technology? Turkish On-line J. Educ. Technol. 8(1):1303-6521.

Karsten R, Roth R (1998). Computer self-efficacy: A practical indicator of student computer competency in introductory IS courses. MIS Q, 1(3):61-68.

Karsten R, Schmidt D (2008). Business student computer self-efficacy: Ten years later. J. Inform. Syst. Educ. 19(4):445-453.

Korobili S, Togio A, Molliori A (2010). Computer anxiety and attitudes among undergraduate students in Greece. Comput. Hum. Behav. 26:399-405. doi:10.1016/j.chb.2009.11.011.

Özçelik H, Kurt AA (2007). Primary school teachers' computer self efficacies: sample of BALIKESIR. Elementary Educ. Online. 6(3):441451.

Pamuk S, Peker D (2009). Turkish pre-service science and mathematics teachers' computer related self-efficacies, attitudes and the relationship between these variables. Comput. Educ. 53:454-461.

Papastergiou M (2007).Are computer science and information technology still masculine fields? High school students' perceptions and career choices. Comput. Educ. (51):594608.doi:10.1016/j.compedu.2007.06.009.

Papastergiou M ( 2010).Enhancing physical education and sport science students' self-efficacy and attitudes regarding information and communication technologies through a computer literacy course. Comput. Educ. 54(1):298-308.doi:10.1016/j.compedu2009.08.015.

Saleh HK (2008). Computer self-efficacy of university faculty in Lebanon. Educ. Technol. Res. Dev. 56:229-240. doi:10.1007/s114230079084-z.

Stephens P (2006). Validation of the business computer self-efficacy scale: assessment of the computer literacy of incoming business students. J. Educ. Comput. Res. 34(1):29-46.

Şimşek A (2011). The relationship between computer anxiety and computer self-efficacy. Contemporary Educ. Technol. 2 (3):177-187.

Teo T (2008). Pre-service teachers' attitude toward computer use: A Singapore survey. Austr. J. Educ. Technol. 24(4):413-424.

Tezci E (2011). Turkish primary school teachers' perceptions of school culture regarding ICT integration. Educ. Technol. Res. Dev. 53(3):429-443.

Ünlü H, Süel E (2014). Computer self-efficacy of prospective physical education teachers. J. Efficiency Responsibility Educ. Sci. 7(2):33-36.

Zorba E (2011). Identifying the computer competency levels of recreation department undergraduates. Turk. Online J. Educ. Technol. 10(4):211-220. 